Available online on 15.03.2019 at http://jddtonline.info
(c) 2011-18, publisher and licensee JDDT, This is an Open Access article which permits unrestricted
non-commercial use, provided the original work is properly cited
Open Access to Pharmaceutical and Medical Research

Open $\odot$ Access

Review Article

\title{
Ayurveda and Modern Perspective on Diseases Associated with Ahara: A Review
}

\author{
Dr. Ranjita Naharia1, Dr. Mariya Husain² \\ ${ }^{1}$ Assistant Professor, Govt. Ashtang Ayurved College, Indore (MP) India. \\ ${ }^{2}$ Associate Professor, Parul Institute of Ayurved, Vadodara (Gujarat) India.
}

\begin{abstract}
Ahara (food) is considered as one of the most important factor in life and it is believe that the normal \& abnormal physiological functioning mainly depends upon the quality of food consumed. Consumption of proper diet in appropriate manner may offer good health status while intake of unwholesome food stuffs can lead to disease condition. Ahara provides strength, complexion and Oja to the body, it play vital role towards longevity \& boost mental strength also. The Rasa, Guna, Virya and Vipaka of Ahara considered responsible for the equilibrium of the Dosha and Dhatu. The consumption of proper diet not only offers nutritional value but also acts as preventive measure towards many diseases. The Ahara if not taken in proper manner then various ailments may be observed including consequences of Virudha-Ahara, present article described importance of Ahara and diseases originated from bad food habits.
\end{abstract}

Keywords: Ayurveda, Ahara, Diseases, Virudha-Ahara.

Article Info: Received 28 Jan 2019; Review Completed 03 March 2019; Accepted 06 March 2019; Available online 15 March 2019

\section{Cite this article as:}

Naharia R, Husain M, Ayurveda and Modern Perspective on Diseases Associated with Ahara: A Review, Journal of Drug Delivery and Therapeutics. 2019; 9(2):514-516 http://dx.doi.org/10.22270/jddt.v9i2.2405

*Address for Correspondence:

Dr. Ranjita Naharia, Assistant Professor, Govt. Ashtang Ayurved College, Indore (MP) India.

\section{Introduction}

Ayurveda the science of traditional Indian medicine described various principles related to mental and physical well being of whole society, further it was extended that the dietary habits play important role to acquire healthy mental and physical status. Food (Ahara) provides energy for various biochemical processes, boost growth mechanism, enhances process of repairing and regeneration. The ayurveda literatures emphasize that intake of balanced diet help to fulfill need of body in all aspect. Ayurveda described diet as a one of the "pillar" out of the "three pillars of life" (Tri-Upastambha).

Vata, Pitta \& Kapha are Tridosha and considered responsible for normal and abnormal physiological functioning of body, it is believe that biochemical processes associated with digestion and assimilation of food articles influences this Tridoshic balance in terms of various means. If Ahara aggravates Doshas then diseases condition may be seen while pacification of Dosha contributes towards the normal physiology (healthy condition).

Table 1: Food recommended for Dosha balancing.

\begin{tabular}{|c|l|l|}
\hline \multicolumn{3}{|c|}{ Food Pacify (balances) Dosha } \\
\hline $\mathbf{1}$ & Vata & Butter, grains, nuts and vegetables. \\
\hline $\mathbf{2}$ & Pitta & Cooked grains, salads, milk and seeds. \\
\hline $\mathbf{3}$ & Kapha & Intense foods, millet, corn flour, buckwheat and quinoa. \\
\hline \multicolumn{3}{|c|}{ Food Vitiates (Disturbed) Dosha } \\
\hline $\mathbf{1}$ & Vata & Fruits, raw salads and beans. \\
\hline $\mathbf{2}$ & Pitta & Sour, hot \& spicy foods, fermented foods; yogurt and vinegar. \\
\hline $\mathbf{3}$ & Kapha & Dairy products, cheese, meat, nuts and rice. \\
\hline
\end{tabular}


Guna, Rasa and Swabhava are the major qualities of Ahara which offers beneficial effect on body, however these qualities of Ahara also leads incompatibility (Viruddha Aahara) if food not consumed in proper manner.
The six Rasa indicates basic tastes of food and each Rasa refers specific elements of Panchamahabhoota and exerts specific effect on the Tridoshas \& Dhatus accordingly:

Table 2: Rasa of Ahara \& their Corresponding Panchamahabhoota Elements

\begin{tabular}{|c|c|c|}
\hline S. No. & Rasa & Corresponding Panchamahabhoota Elements \\
\hline $\mathbf{1}$ & Madhura Rasa & Prithvi \& Aap \\
\hline $\mathbf{2}$ & Amla Rasa & Prithvi \& Agni \\
\hline $\mathbf{3}$ & Lavana Rasa & Aap \& Agni \\
\hline $\mathbf{4}$ & Katu Rasa & Agni \& Vayu \\
\hline $\mathbf{5}$ & Thikta Rasa & Vayu \& Akash \\
\hline $\mathbf{6}$ & Kashaya Rasa & Prithvi \& Vayu \\
\hline
\end{tabular}

Aahara (diet) should be taken by considering factors such as; Desh, Kala, Prakriti and Vayah. The concept of Viruddha Ahara help to avoid any chances of complication arises due to the consumption of incompatible foods. The intake of unwholesome food stuffs and avoidance of concept of Viruddha Ahara may leads various ailments and instances of such cases increasing day by day due to the complexity of modern life style. Moreover industrialization, poor hygienic condition, pollution and huge availability of junk foods have increased the risk of contamination of food and water, thus lot of diseases reported currently in hospital originated from contaminated foods or Viruddha Ahara. Present article described importance of Ahara and diseases originated from wrong food habits.

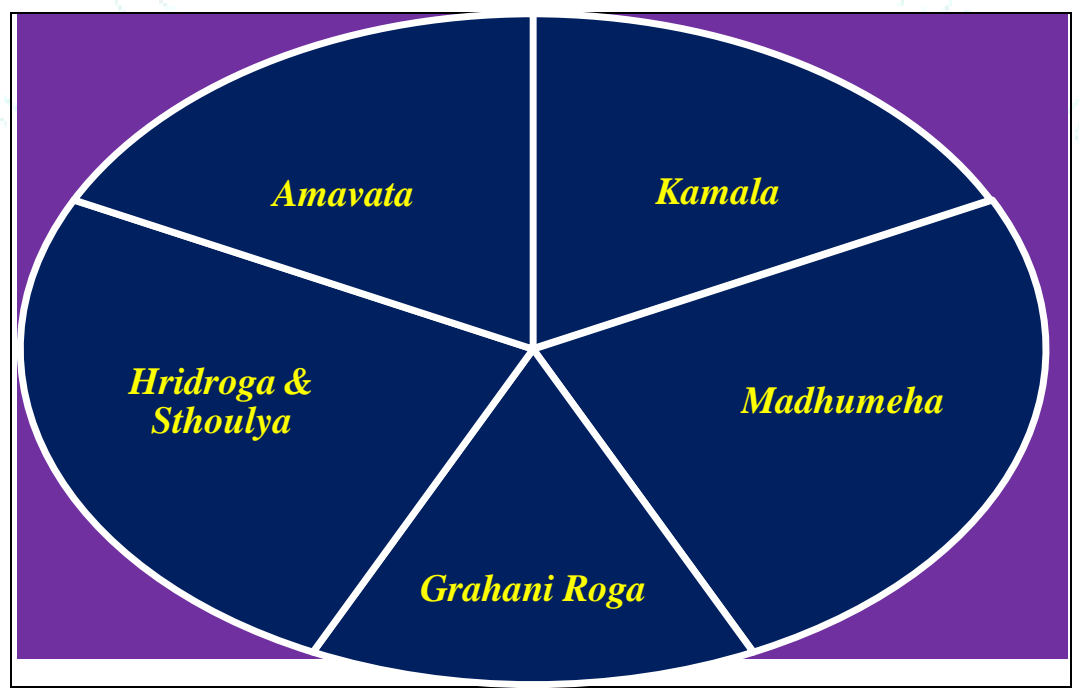

Figure 1: Diseases their pathogenesis mainly depends upon Ahara.

\section{Aahara \& Diseases:}

Acharya Charaka has mentioned that incompatible Ahara can lead number of disorders. Immune system, endocrine system, digestive system, nervous system and circulatory system affected by consumption of incompatible Aahara. The some of them are as follows:

$>$ Indriyopghatakara: Andhya, Shandhya, Bhagandara, Jwara and Pinasa.

> Dhatu Parinamkar: Dakodara, Visarpa, Pandu, Aamvisha, Kushtha, Santandosha, Visphota, Galagraha, Grahani and Amlapitta.

> Manasa Vyadhi: Unmada and Mada.

\section{Diet Specific Diseases:}

$>$ Extreme hot food may causes disease such as; Mada, Daha, Trushna and Bhrama etc.

ISSN: 2250-1177
$>$ Atisnigdha food inhibits the process of digestion since it is 'Guru' in nature and therefore causes Praseka, Hridayagaurava and Alasya, Aruchi, etc.

> Asnigdha or ruksha Ahara decreases Bala and Varna, producing dryness of skin and constipation.

$>$ Similarly malnutrition and excessive consumption of sour and hot food stuffs may leads Shukra Dhatu Dushti.

$>$ Eating too fast may creates Vimargagamanam which further leads Annaja Hikka.

$>$ Abhojana, Ajeerna, Atibhojana, Asatmya Bhojana and Vishamashana may induces symptoms of Grahani dosha.

> Snehavibramat, RutuVaishamya, Kala Vaishamya, Vega Vidharanat and Swapna Viparyaya may produces symptoms of Agnidosha. 
$>$ Excessive exercise just after Snigdha Ahara may precipitate symptoms of Amavata.

\section{Modern Concept of Diseases and Food:}

The modern medical science also mentioned that consumption of certain food stuffs may enhances chances of specific pathological conditions including; diarrhea, constipation, gastric burn and food poisoning. These all conditions may occurs for shorter period of time thus considered as acute pathological conditions related to food consumption, however disease like; obesity and diabetes may considered as chronic conditions related to bad food habits. Consumption of unwholesome food stuffs along with stress or anxiety accumulates symptoms of heart diseases and blood pressure. Food allergies is one of the another aspect of modern science, certain food stuffs may produces adverse reactions and this adversity vary person to person means some person are allergic to specific food while other not. The foods containing intense essence or odour may be considered allergic for individuals in the population. Food poisoning is type of illness occur due to the consumption of contaminated food, the chances of microbial contamination (bacteria, viruses and environmental toxins) more with nonvegetarian foods than vegetarian food stuffs. Mushrooms, seafood and food preservative also produces specific adverse reaction depending upon demographical classification.

\section{Ayurveda recommended some combinations to prevent food originated diseases:}

* Go-Ghee, takra, navaneet.

* Mudaga, masura, adhaki as digestible protein.

* Manda, vilepi, peya, yusha

* Rakta-shali, Shashtika, Shali, Godhuma and yava as carbohydrates and fiber.

* Saindhav salt daily.

* Dadima, amalaki, haritaki as Tridosha Shamaka.

\section{Combinations to be avoid:}

* Dadhi, Avi dugdha, Kurchika and Avi grita.
* Curd, Kurchika \& fish.

* Uncooked Moolaka \& germinated grains

* Mansa and Madira Sevana, etc.

\section{References}

1. Agnivesha. In: Charaka, Dridhabala, Charaka Samhita, Sutra Sthana, 26/81. Reprint. Vaidya Yadavaji Trikamaji Acharya., editor. Varanasi: Chaukhambha publishing house; 2016. p. 149.

2. Vagbhata. In:Ashtanga Hridaya Samhita Sutra Sthana, $7 / 45$. Reprint. VaidyaA.M.Kunte,Vd. Harishastri Paradkar editor. Varanasi: ChaukhambhaSamskrita Samsthana; 2011. p. 137.

3. Sushruta. In: Sushruta Samhita, Sutra Sthana, 20/16. Reprint. Vaidya Yadavaji Trikamaji Acharya., editor. Varanasi: Chaukhambha Surbharati, Prakashana; 2003. P.96

4. Agnivesha. In: Charaka, Dridhabala, Charaka Samhita, Sutra Sthana, 26/106. Reprint. Vaidya Yadavaji Trikamaji Acharya., editor. Varanasi: Chaukhambha publishing house; 2016. p. 151.

5. Charaka Samhita (1994) Ayurveda Deepika commentary by Chakrapani Datta: Shareera sthana 6/12, Chaukhamba Sanskrit Sansthan, Varanasi, India.

6. Charaka Samhita (1994) Ayurveda Deepika commentary by Chakrapani Datta: Sutra sthana 11/35, Chaukhamba Sanskrit Sansthan, Varanasi, India.

7. Motilal Banarasi Das (1963) Astanga Hridaya Sarvanga Sundari Tika commentary by Sh. Lal Chandra Vaidya: Sutra 13/25, Varanasi, India.

8. P.S. Rao (2005) Ashtanga Sangraha (vol1): Sutra 20/2, Choukhamba Krishnadas Academy, Varanasi, India.

9. Motilal Banarasi Das (1963) Astanga Hridaya Sarvanga Sundari Tika commentary by Sh. Lal Chandra Vaidya : Sutra 10/1, Varanasi, India.

10. Motilal Banarasi Das (1963) Astanga Hridaya Sarvanga Sundari Tika commentary by Sh. Lal Chandra Vaidya: Sutra 13/10, Varanasi, India.

11. Charaka Samhita (1994) Ayurveda Deepika commentary by Chakrapani Datta: Vimana sthana 3/17, Chaukhamba Sanskrit Sansthan, Varanasi, India.

12. Charaka Samhita (1994) Ayurveda Deepika commentary by Chakrapani Datta: Sutra 5/4, Chaukhamba Sanskrit Sansthan Varanasi, India. 